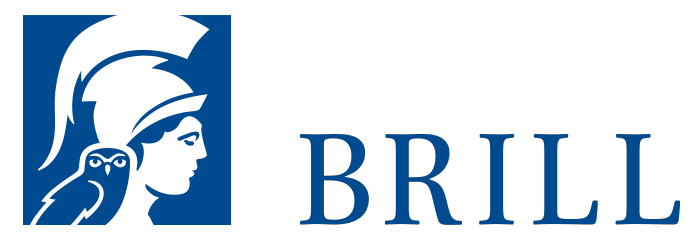

\title{
Philosophie und hermeneutische Theologie
}

Heidegger, Bultmann und die Folgen

Author: Otto Pöggeler

Die Zusammenarbeit zwischen dem Philosophen Martin Heidegger und dem Theologen Rudolf Bultmann während ihrer gemeinsamen Marburger Jahre (1923-1928) hat wenigstens zwei Generationen von Theologen geprägt. Inzwischen rückte ein Theologe und Philosoph wie Ernst Troeltsch, der damals schroff kritisiert wurde, in den Mittelpunkt neuer Interessen. Von Carl Schmitt her wurde (durch die Schule von Joachim Ritter und durch Hans Blumenberg) die Auseinandersetzung um Theologie und Philosophie neu artikuliert. Die Wege von Bultmann und Heidegger werden von ihren Anfängen her aufgeschlüsselt, damit über der Zusammenarbeit nicht die unterschiedlichen Ansätze vergessen werden. Dass die Begegnung zu einer Trennung führen musste, wird aufgezeigt. Zur Sprache kommen auch die eigenständigen Wege etwa von Heinrich Schlier, Ernst Käsemann, Hans Hübner. Durch japanische Schüler wie Nishitani kam Heidegger zu einer intensiven Auseinandersetzung mit Ostasien. Ein Philosoph wie Leo Strauß, ein Theologe wie Eugen Biser, ein Schriftsteller wie Hans Erich Nossack verweisen auf das Zusammenspiel von Literatur, Philosophie und Theologie. Am Schluss des Buches steht der Versuch, von der Philosophie her systematisch zu bestimmen, was hermeneutische Theologie sein kann.

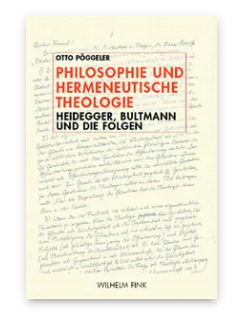

Pages: 313

Seiten

Language:

German

Subjects:

General,

Philosophy

Publisher: Brill |

Fink

E-Book (PDF)

Released online:

o7 Oct 2019

ISBN: 978-3-

8467-4403-1

List price

USD $\$ 63.00$

Paperback

Publication date:

o1 Apr 2009

ISBN: 978-3-

7705-4403-5

List price

USD $\$ 63.00$ 
For more information see brill.com

Order information: Order online at brill.com +44330 333 0049 | customerservices@brill.com Submission information: brill.com/authors

Titles published by Brill | Fink, Brill | mentis or Brill | Schöningh: +49(o)715413279216| brill@brocom.de 